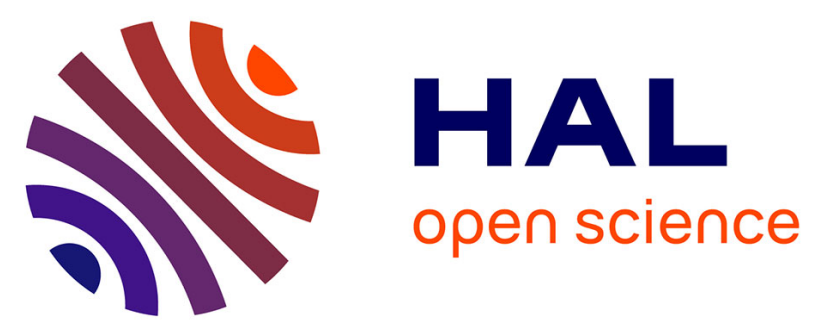

\title{
Valorization of algal waste via pyrolysis in a fixed-bed reactor: production and characterization of bio-oil and bio-char
}

\author{
Adil Aboulkas, H. Hammani, M. El Achaby, E. Bilal, Abdellatif Barakat, K. \\ El Harfi
}

\section{To cite this version:}

Adil Aboulkas, H. Hammani, M. El Achaby, E. Bilal, Abdellatif Barakat, et al.. Valorization of algal waste via pyrolysis in a fixed-bed reactor: production and characterization of bio-oil and bio-char. Bioresource Technology, 2017, 243, pp.400-408. 10.1016/j.biortech.2017.06.098 . hal-01602526

\section{HAL Id: hal-01602526 https://hal.science/hal-01602526}

Submitted on 26 May 2020

HAL is a multi-disciplinary open access archive for the deposit and dissemination of scientific research documents, whether they are published or not. The documents may come from teaching and research institutions in France or abroad, or from public or private research centers.
L'archive ouverte pluridisciplinaire HAL, est destinée au dépôt et à la diffusion de documents scientifiques de niveau recherche, publiés ou non, émanant des établissements d'enseignement et de recherche français ou étrangers, des laboratoires publics ou privés. 


\section{Accepted Manuscript}

Valorization of algal waste via pyrolysis in a fixed-bed reactor: production and characterization of bio-oil and bio-char

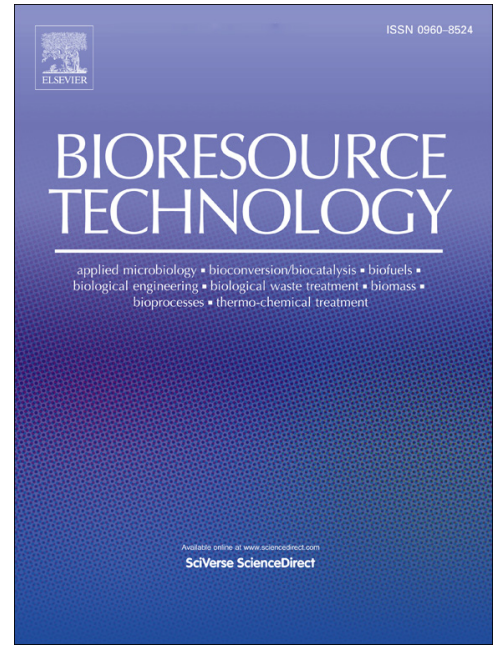

A. Aboulkas, H. Hammani, M. El Achaby, E. Bilal, A. Barakat, K. El harfi

PII:

S0960-8524(17)31002-7

DOI:

http://dx.doi.org/10.1016/j.biortech.2017.06.098

Reference:

BITE 18335

To appear in:

Bioresource Technology

Received Date: $\quad 10$ May 2017

Revised Date: $\quad 16$ June 2017

Accepted Date: $\quad 17$ June 2017

Please cite this article as: Aboulkas, A., Hammani, H., El Achaby, M., Bilal, E., Barakat, A., El harfi, K., Valorization of algal waste via pyrolysis in a fixed-bed reactor: production and characterization of bio-oil and bio-char, Bioresource Technology (2017), doi: http://dx.doi.org/10.1016/j.biortech.2017.06.098

This is a PDF file of an unedited manuscript that has been accepted for publication. As a service to our customers we are providing this early version of the manuscript. The manuscript will undergo copyediting, typesetting, and review of the resulting proof before it is published in its final form. Please note that during the production process errors may be discovered which could affect the content, and all legal disclaimers that apply to the journal pertain. 


\title{
Valorization of algal waste via pyrolysis in a fixed-bed reactor: production and
} characterization of bio-oil and bio-char

\author{
A. Aboulkas ${ }^{1,2,3^{*}}$, H. Hammani ${ }^{1,4}$, M. El Achaby ${ }^{3}$, E. Bilal ${ }^{5}$, A. Barakat ${ }^{2,3}$, \\ K. El harfi ${ }^{1}$ \\ 1 Laboratoire Interdisciplinaire de Recherche des Sciences et Techniques, Faculté \\ polydisciplinaire de Béni-Mellal, Université Sultan Moulay Slimane, BP 592, 23000 Béni- \\ Mellal, Morocco. \\ ${ }^{2}$ IATE, CIRAD, Montpellier SupAgro, INRA, Université de Montpelier, 34060, Montpellier, \\ France. \\ ${ }^{3}$ Materials Science and Nanoengineering Department, Mohamed 6 Polytechnic University, Lot \\ 660-Hay MoulayRachid, 43150 Benguerir. \\ ${ }^{4}$ Univ Hassan 1, Laboratoire de Chimie et Modélisation Mathématique, 25000 Khouribga, \\ Morocco. \\ ${ }^{5}$ R\&D OCP, OCP Group, Complexe industriel Jorf Lasfar. BP 118 El Jadida, Morocco.
}

\begin{abstract}
:
The aim of the present work is to develop processes for the production of bio-oil and bio-char from algae waste using the pyrolysis at controlled conditions. The pyrolysis was carried out at different temperatures $400-600{ }^{\circ} \mathrm{C}$ and different heating rates 5-50 ${ }^{\circ} \mathrm{C} / \mathrm{min}$. The algal waste, bio-oil and bio-char were successfully characterized using Elemental analysis, Chemical composition, TGA, FTIR, ${ }^{1} \mathrm{H}-\mathrm{NMR}, \mathrm{GC}-\mathrm{MS}$ and SEM. At a temperature of $500{ }^{\circ} \mathrm{C}$ and a heating rate of $10{ }^{\circ} \mathrm{C} / \mathrm{min}$, the maximum yield of biooil and bio-char was found to be 24.10 and $44.01 \mathrm{wt} \%$, respectively, which was found to be strongly influenced by the temperature variation, and weakly affected by the heating rate variation. Results show that the bio-oil cannot be used as bio-fuel, but can be used
\end{abstract}


as a source of value-added chemicals. On the other hand, the bio-char is a promising candidate for solid fuel applications and for the production of carbon materials.

Keywords: Pyrolysis; Algal waste; Bio-oil; Bio-char; Characterization

\section{Introduction}

Biomass has attracted a great attention as a source for renewable and clean energy (Chen et al., 2015; Ertaş and Hakkı Alma, 2010). Biomass can be converted directly into liquid, gaseous and solid fuels, usable for transport, heat and power production (Demiral et al., 2012). Among a large variety of biomass resources, marine biomass has been considered to be a precious material for the third generation bio-fuels feedstock (Demirbas, 2011; Li et al., 2012). The marine areas of Morocco include almost $3500 \mathrm{~km}$ of coastline (Ainane, 2011). Red macroalgae (Gelidium sesquipedale) are considered economically valuable resources due to their ability to produce high yields of commercially valuable biomass (Hanif et al., 2014). Morocco the third producer in the world (Mouradi-Givernaud et al., 1999). The Gelidium represents 90\% of the harvest of the marine algae treated locally and that generates an important quantity of waste (production of 870 tons/years) that cannot be treated very well (Ennouali et al., 2006). Biochemical and thermochemical processes are used for converting waste to bio-fuel and/or other products. Among these technologies, pyrolysis is a promising technology, more favorable and economical for converting algal biomass into energy fuels (FerreraLorenzo et al., 2014a, 2014b; Francavilla et al., 2015; Hui Zhao et al., 2013). The thermal decomposition in the absence of oxygen and at temperatures $\left(400-600{ }^{\circ} \mathrm{C}\right)$ 
results in liquid products (bio-oil or pyrolytic oil); carbon-rich solid residues (bio-char); and gaseous products (Chaiwong and Kiatsiriroat, n.d.; Choi et al., 2016; Francavilla et al., 2015; Hu et al., 2013; Ross et al., 2008; Yanik et al., 2013). Bio-oil is considered to be a very promising biofuel and may be used as fuel for heat, power or combined heat and power, or as an intermediate feedstock for various chemicals and liquid transport fuels production. The bio-char is also a useful product that can be used for soil amendment and to sequester carbon in the soil, bio-energy (high calorific value) or environmental-contaminant removal. The Characteristics of pyrolysis products depend on the experimental parameters: final temperature, heating rate, residence time, type of pyrolysis reactor, type of biomass used...etc. The effects of each factor are closely interconnected, which requires more knowledge of the operating conditions of the pyrolysis process to produce bio-oil and bio-char with excellent fuel properties. A number of studies regarding bio-oil and bio-char production from various sources of biomass have showen that liquid and solid fuels can be produced from biomass (Ben Hassen-Trabelsi et al., 2014; Chaiwong and Kiatsiriroat, n.d.; Choi et al., 2016; Demiral et al., 2012; Ertaş and Hakkı Alma, 2010; Hu et al., 2013; Kraiem et al., 2015; Onay, 2007; Onay and Koçkar, 2006, 2004; Ross et al., 2008; Yanik et al., 2013). However, very little information is available on the process of pyrolysis of macroalgae into bio-oil and bio-char and analysis of the characteristics of these products (Chaiwong and Kiatsiriroat, n.d.; Choi et al., 2016; Hu et al., 2013; H. Zhao et al., 2013). Hu et al. (2013) have reported the properties of bio-oils produced by pyrolysis of blue-green algae blooms. The experiments were performed in a fixed-bed reactor and the effects of pyrolysis temperature, particle size and nitrogen flow rate on product yields were studied. The results showed that a maximum oil yield of $54.97 \%$ was obtained at a final 
pyrolysis temperature of $500{ }^{\circ} \mathrm{C}$, a particle size below $0.25 \mathrm{~mm}$ and a nitrogen flow rate of $100 \mathrm{~mL} \mathrm{~min}^{-1}$. The bio-oil was characterized with a high heating value of $31.9 \mathrm{MJ} \mathrm{kg}^{-}$ ${ }^{1}$ and an $\mathrm{O} / \mathrm{C}$ molar ratio of 0.16 at optimum conditions. The authors have shown that the pyrolysis of algal biomass is a promising process for both renewable fuel production and lake environment improvement. Zhao et al. (2013) also investigated the properties of bio-oil produced by fast pyrolysis of macroalgae in a Free-fall Reactor. The bio-oil obtained was analyzed by elemental, GC-MS, and FT-IR analysis. The results showed that the average heat value was $25.33 \mathrm{MJ} \mathrm{kg}^{-1}$ and the oxygen content was $30.27 \mathrm{wt} \%$. The results suggested that macroalgae presents as a good bio-oil feedstock candidate. Choi et al. (2016) pyrolyzed Brown algae in a fixed bed reactor under pyrolysis temperature $\left(430-530{ }^{\circ} \mathrm{C}\right)$ and holding time (4-10 min). The maximum yields of bio-oil and bio-char were approximately 48.4 and $32.3 \mathrm{wt} \%$, respectively, when prepared at 450 ${ }^{\circ} \mathrm{C}$ for $8 \mathrm{~min}$. The results showed that the bio-char has properties, including a comparatively high nutrient content $(\mathrm{Ca}, \mathrm{K}, \mathrm{Mg}, \mathrm{N}$, and $\mathrm{P})$, that make it suitable for use as a soil additive, and for long-term soil carbon sequestration. Francavilla et al. (2015) carried out pyrolysis of G.gracilis (macroalgae) residue in order to investigate the production of bio-oil and bio-char within a pyrolysis temperature range of $400-600{ }^{\circ} \mathrm{C}$. Results showed that the bio-oil yield is high $(65 \mathrm{wt} \%)$ at a pyrolysis temperature $500{ }^{\circ} \mathrm{C}$ and a bio-char yield ranging between $33 \mathrm{wt} \%\left(400^{\circ} \mathrm{C}\right)$ and $26.5 \mathrm{wt} \%\left(600{ }^{\circ} \mathrm{C}\right)$. Bae et al. (2011) studied the effect of pyrolysis temperature on production and characterization of bio-oil from three marine macroalgae, and they concluded that the bio-oil yield reached a maximum, within the range of $37.5-47.4 \mathrm{wt} . \%$, at $500{ }^{\circ} \mathrm{C}$. The compounds identified suggest that pyrolysis can be used to produce bio-oils for various uses, such as chemical feedstock, through further treatment. However, these studies only focused 
on bio-oil analyses, a comprehensive characterization including both bio-oil and biochar is necessary.

In this study, algal waste after extraction of agar-agar was chosen as source of algal biomass because there is no study on the influence of operating conditions on production and characterization of bio-oil and bio-char from algal waste via pyrolysis. The major challenge in the energy field is the search for process to convert biomass wastes into biofuel with excellent fuel properties. Aim of this study was (i) to investigate the influence of experimental parameters on the pyrolysis of algal waste; (ii) to determine the suitable experimental parameters to achieve maximum bio-oil yield; and (iii) to characterize the bio-oil produced under suitable pyrolysis conditions using elemental analysis, TGA, FTIR, ${ }^{1} \mathrm{H}-\mathrm{NMR}, \mathrm{GC}-\mathrm{MS}$ is characterized. The use of chemical and physical Characteristics was also performed in order to investigate the proprieties of the produced bio-char.

\section{Materials and methods}

Algal waste used in this study as a feedstock was obtained from the industrial processing of red macroalgae to obtain Agar product (SETEXAM company, KenitraMorocco). Prior to use, algal waste was air dried, ground and sieved to obtain particles in the ranges of $0.5-1 \mathrm{~mm}$. Thermogravimetric curves were obtained at four different heating rates $\left(5,10,20\right.$ and $\left.50{ }^{\circ} \mathrm{C} \min ^{-1}\right)$ between $105^{\circ} \mathrm{C}$ and $900{ }^{\circ} \mathrm{C}$. Nitrogen gas was used as an inert purge gas to displace air in the pyrolysis zone, thus avoiding unwanted oxidation of the sample. A flow rate of around $60 \mathrm{ml} \mathrm{min}^{-1}$ was fed to the system from a point below the sample and a purge time of $60 \mathrm{~min}$ (to be sure the air was eliminated 
from the system and the atmosphere is inert). The balance can hold a maximum of 45 $\mathrm{mg}$; therefore, all sample amounts used in this study averaged approximately $20 \mathrm{mg}$. Proximate analysis was conducted using a thermogravimetric analyser (METTLER TOLEDO-TGA/DSC 3+). The moisture content is determined by the mass loss after the sample is heated to $105^{\circ} \mathrm{C}$ under $\mathrm{N}_{2}$. The volatile matter corresponds to the mass loss between 105 and $900{ }^{\circ} \mathrm{C}$ under $\mathrm{N}_{2}$. Fixed carbon is the solid combustible material that leads to the mass loss at $900{ }^{\circ} \mathrm{C}$ when the atmosphere is switched from $\mathrm{N}_{2}$ to air (Saldarriaga et al., 2015); the residue left is the ash content. Ultimate analysis for C, $\mathrm{H}$, $\mathrm{N}$ and $\mathrm{S}$ content was performed using an elemental analyzer (vario MICRO cube V4.0.2). The $\mathrm{H} / \mathrm{C}, \mathrm{O} / \mathrm{C}$ molar ratios and empirical formula were calculated from elemental composition. Higher heating value (HHV) of samples was experimentally measured using a bomb calorimetric (Model 1261, Parr Instruments) according to ASTM D 5865-04.

\subsection{Pyrolysis procedure}

The pyrolysis experiments were performed using a stainless steel fixed-bed reactor. The experiments were carried out in two series. The first group of the pyrolysis experiments was performed to determine the effect of the pyrolysis temperature on the pyrolysis product yields and the pyrolysis conversion. A sample of $20 \mathrm{~g}$ of algal waste was placed in the reactor and nitrogen gas (flow rate of $0.1 \mathrm{~L} / \mathrm{min}$ ) was introduced for $15 \mathrm{~min}$ to remove air in the reactor. The sample was pyrolyzed from an initial temperature $\left(25^{\circ} \mathrm{C}\right)$ to a final temperature $\left(350,400,450,500,550\right.$ or $\left.600^{\circ} \mathrm{C}\right)$ with a heating rate of 10 ${ }^{\circ} \mathrm{C} / \mathrm{min}$ and held for $20 \mathrm{~min}$ at the final temperature. The liquid products were condensed in a trapping system and recovered by washing with dichloromethane 
(DCM). The aqueous phase was separated from bio-oil by decantation. The anhydrous sodium sulphate was added into the bio-oil and the solvent mixture to remove any remaining water. After the solvent was separated from the bio-oil using a rotary evaporator, the bio-oil was weighed and its yield was determined. The bio-char in the reactor was weighed and the gas yield was calculated by determining the weight difference. The second group of experiments was performed with four heating rates, namely, $5,10,20$ and $50{ }^{\circ} \mathrm{C} / \mathrm{min}$ at the pyrolysis temperature of $500^{\circ} \mathrm{C}$. This was in order to examine the influence of heating rate on the pyrolysis product yields. In this study, the pyrolysis experiments were repeated three times to confirm the reproducibility. The products yields are mean values of three equivalent experiments.

$$
\begin{gathered}
\text { Bio }- \text { oil yield }(\%)=\frac{\text { bio }- \text { oil collected weight }}{\text { initial feedstock weight }} \times 100 \\
\text { Bio }- \text { char yield }(\%)=\frac{\text { Bio }- \text { char weight }}{\text { initial feedstock weight }} \times 100 \\
\text { Gas yield }(\%)=100-(\text { bio }- \text { oil yield }+ \text { bio }- \text { char yield })
\end{gathered}
$$

\subsection{Bio-oil and bio-char characterization}

The bio-oil selected for the characterization was that which gave the maximum bio-oil yield at the temperature of $500{ }^{\circ} \mathrm{C}$ and heating rate of $10{ }^{\circ} \mathrm{C} / \mathrm{min}$. The bio-char obtained at the same conditions was also characterized.

\subsubsection{Elemental composition and ash content}

The elemental composition (CHN-O) and ash content of the bio-oil and bio-char were determined with the same methods used for raw material. 


\subsubsection{Fourier Transform Infrared Spectroscopy (FTIR)}

FTIR spectroscopic analyses were performed to determine the distribution of functional groups present in pyrolysis products (bio-oil and bio-char). The FTIR spectra of the produced bio-oil and bio-char were recorded using a bruker tensor 27 infrared spectrometer in the wavelength range of $400-4000 \mathrm{~cm}^{-1}$ with a resolution of $4 \mathrm{~cm}^{-1}$ and accumulation of 16 scans.

\subsection{3. ${ }^{1} H$-NMR spectroscopy}

${ }^{1} \mathrm{H}-\mathrm{NMR}$ spectra were recorded on $600 \mathrm{MHz}$ Bruker spectrospin instruments. The biooil sample was diluted with $\mathrm{CDCl}_{3}$.

\subsubsection{Gas Chromatography-Mass Spectrometry (GC-MS)}

Gas Chromatography-Mass Spectrometry (Thermo scientific ISQ single quadrupole) was used to analyze the bio-oil fraction. By comparing the recorded mass spectra of compounds with those given in the NIST2008 c2.0/Xcalibur data system library, provided by the instrument software, compound identification was done. Bio-oil were separated by silica capillary column, using helium as the carrier gas $(1.2$ $\mathrm{mL} / \mathrm{min})$. The injection volume was $1 \mu \mathrm{L}$ using a 20:1 split ratio and an injector temperature of $260{ }^{\circ} \mathrm{C}$. The GC temperature sequence was $70{ }^{\circ} \mathrm{C}$ start, hold 2 min, ramp at $10{ }^{\circ} \mathrm{C} / \mathrm{min}$ to $300{ }^{\circ} \mathrm{C}$ and hold at $300{ }^{\circ} \mathrm{C}$ for $5 \mathrm{~min}$.

\subsubsection{Scanning Electron Microscopy (SEM)}


The morphology of raw waste and its bio-char was investigated by a scanning electron microscope (phenom Pro X). SEM was carried out using an electron acceleration of 15 $\mathrm{kV}$. Images were taken at a magnification of $3000 \times$.

\section{Results and discussion}

\subsection{Algal waste characteristics}

The main characteristics of algal waste including the results of proximate and ultimate analyses are given in Table 1, where composition analysis gave $35.27 \mathrm{wt} \% \mathrm{C}, 4.71 \mathrm{wt} \%$ $\mathrm{H}, 4.44 \mathrm{wt} \% \mathrm{~N}, 0.73 \mathrm{wt} \% \mathrm{~S}, 54.85 \mathrm{wt} \% \mathrm{O}$. The heating value of the algal waste was $14.98 \mathrm{MJ} / \mathrm{kg}$, which is relatively high compared to other agricultural residues (Nanda et al., 2016). It was observed that the algal waste contains a high ash content (12.09\%) which is consistent with previous observations of the high ash content in aquatic flora from natural ecosystems, including micro- and macro-algae. The presence of high ash content in the algal waste favors the formation of char since inorganic compounds in the ash are known to catalyze the formation of char during pyrolysis (Maddi et al., 2011).

\subsection{Thermogravimetric analysis of algal waste}

The thermogravmetric analysis was performed to determine the pyrolysis process temperature. The algal waste was heated from $105^{\circ} \mathrm{C}$ to $900{ }^{\circ} \mathrm{C}$ at four heating rate of 5 , 10,20 and $50{ }^{\circ} \mathrm{C} / \mathrm{min}$ in a nitrogen atmosphere. Figure 1 shows the behavior of the algal waste under these conditions. The main mass change seen between $250{ }^{\circ} \mathrm{C}$ and $600{ }^{\circ} \mathrm{C}$ is attributed to de-volatilization stage in which the pyrolysis main process occurred. This mass loss represents the decomposition of carbohydrate and the protein content (Kim et al., 2013). The maximum thermal degradation of the algal waste was at approximately 
$340-380{ }^{\circ} \mathrm{C}$ (depending on heating rate). Moreover, a significant proportion of inorganic materials in kelps decompose at $600-800{ }^{\circ} \mathrm{C}$, probably a consequence of metal carbonates (Norouzi et al., 2016). The TGA curve indicates that over $60 \mathrm{wt} \%$ of the algal waste is thermally degraded when the reaction temperature is beyond $380{ }^{\circ} \mathrm{C}$. It follows that the algal waste pyrolysis should be performed at temperatures higher than $380^{\circ} \mathrm{C}$. For this reason, algal waste pyrolysis at the five reaction temperatures of $400,450,500$, 550 and $600{ }^{\circ} \mathrm{C}$ were considered.

\subsection{FTIR characterization of algal waste}

The FTIR spectrum of algal waste is shown in Figure 2. The FTIR analysis was conducted to observe the organic functional groups. The wide band between 3500-3100 $\mathrm{cm}^{-1}$ assigned to $\mathrm{O}-\mathrm{H}$ stretching vibrations. This band indicates the presence of polysaccharides and proteins in the algal waste. The absorption band located at 1640 $\mathrm{cm}^{-1}$, originated from conjugated carbonyl groups (located at $\alpha$-position). The $\mathrm{C}-\mathrm{H}$ bending vibrations at $1370 \mathrm{~cm}^{-1}-1422 \mathrm{~cm}^{-1}$, together with the $\mathrm{C}-\mathrm{O}$ bending vibration at $1235 \mathrm{~cm}-1$ were found in the spectra of algal waste, and this suggests the presence of fats and esters (Zou et al., 2009). The absorbance peak at around $1030 \mathrm{~cm}^{-1}$ was also observed and that was possibly from C-O stretching vibrations.

\subsection{Effect of final temperature and heating rate on yields of pyrolysis products}

Pyrolysis temperature is the most important parameter affecting the product yields. The distribution of pyrolysis products from pyrolysis of algal waste at various final pyrolysis temperatures such as $400,450,500,550$ and $600{ }^{\circ} \mathrm{C}$ is as shown in figure $3 \mathrm{a}$. It can be seen that the conversion yield increased from 47.91 to $59.64 \%$ when the pyrolysis 
temperature was increased from 400 to $600{ }^{\circ} \mathrm{C}$. The bio-oil yield was $19.90 \%$ at the lowest temperature of $400{ }^{\circ} \mathrm{C}$, this data reflects incomplete pyrolysis of algal waste. The peak yield of bio-oil was $24.10 \%$ at $500{ }^{\circ} \mathrm{C}$ after which it decreased to $22.30 \%$ at 600 ${ }^{\circ} \mathrm{C}$. The increase in the yield of bio-oil from $400{ }^{\circ} \mathrm{C}$ to $500{ }^{\circ} \mathrm{C}$ is explained by the increase of the primary decomposition of the algal waste or the secondary decomposition of the bio-char residue, as the pyrolysis temperature increases. The decrease in the yield bio-oil from $500{ }^{\circ} \mathrm{C}$ to $600{ }^{\circ} \mathrm{C}$ may be due to the secondary cracking of the pyrolysis vapors at higher temperatures. The yield of bio-char markedly always decreased from 52.09 to $40.36 \mathrm{wt} . \%$, while the yield of gaseous product gradually rose from 21.81 to $31.44 \mathrm{wt} \%$ as the pyrolysis temperature rose from 400 to $600{ }^{\circ} \mathrm{C}$. The decrease in the char yield may be attributed to either the greater primary decomposition of algal waste at higher temperature or the secondary thermal decomposition of the char formed before being entrained out of the reactor. The gas increase is speculated to be owing to the secondary cracking of the char and the pyrolysis vapors.

Due to the maximum oil yield obtained in the first set of experiments, the pyrolysis temperature was held constant at $500^{\circ} \mathrm{C}$. Figure $3 \mathrm{~b}$ shows the pyrolysis product yields were obtained at four heating rates of $5,10,20$ and $50{ }^{\circ} \mathrm{C} / \mathrm{min}$ with the final pyrolysis temperature being $500{ }^{\circ} \mathrm{C}$. The bio-oil yield was $22.30 \%, 24.10 \%, 23.50 \%$ and 22.70 $\%$ for the heating rates of $5,10,20$ and $50{ }^{\circ} \mathrm{C} / \mathrm{min}$, respectively. The bio-char yield decreased from $45.23 \%$ to $42.31 \%$ and the gas yield increased from $26.67 \%$ to 28.69 $\%$ with an increasing heating rate from $5{ }^{\circ} \mathrm{C} / \mathrm{min}$ to $50{ }^{\circ} \mathrm{C} / \mathrm{min}$. The slight decrease in the bio-char yield and the little increase in the gas yield are due to secondary cracking of 
the pyrolysis vapors and secondary decomposition of the bio-char at higher heating rates.

All experiments indicate that the pyrolysis temperature at $500{ }^{\circ} \mathrm{C}$ and the heating rate of $10{ }^{\circ} \mathrm{C} / \mathrm{min}$ are the parameters that result in a maximum bio-oil yield of around $24.10 \%$. It is known that the final temperature has a significant effect on yield and composition of pyrolysis products (Bae et al., 2011; Ben Hassen-Trabelsi et al., 2014; Choi et al., 2016; Hu et al., 2013; Onay, 2007). The increase of the final temperature is always followed by an important decrease of bio-char yield and an increase in the gases amounts. On the other hand, the bio-oil reaches a maximum in the temperature range of 500-550 ${ }^{\circ} \mathrm{C}$. For example, Choi et al. (2016) studied the pyrolysis of brown alga and evaluated the effect of the final temperature $\left(430-530{ }^{\circ} \mathrm{C}\right)$ on product distribution. They found that the bio-char yield steadily decreased from 34.50 to $25.5 \mathrm{wt} \%$, with rising temperature. This was the opposite of the gas yield, which increased from 20.30 to 27.2 $\mathrm{wt} \%$. The yield of bio-oil reached a maximum value of $48.40 \mathrm{wt} \%$ at $450{ }^{\circ} \mathrm{C}$ (48.40wt\%), and then decreased as the temperature increased. Bae et al. (2011) investigated the effect of the pyrolysis temperature $\left(300-600{ }^{\circ} \mathrm{C}\right)$ on the pyrolysis characteristics of bio-oil in a quartz U-tube reactor. They found that the maximum production of bio-oil was achieved at $500{ }^{\circ} \mathrm{C}$. Furthermore, They Argued that this was due to the secondary tar reactions in the vapor phase since the liquid yields decreased while corresponding the gas yields increased at $600{ }^{\circ} \mathrm{C}$. The pyrolysis of macroalgae offers a new opportunity for feedstock production; however, the utilization of bio-oil as a fuel product needs further assessment. Hu et al. (2013) studied the pyrolysis of bluegreen algae blooms in a fixed-bed reactor for bio-oil production. The effect of process parameters such as pyrolysis temperature, particle size and sweep gas flow rate on the 
yields of pyrolysis products and their chemical compositions were investigated. When the temperature was increased from $300{ }^{\circ} \mathrm{C}$ to $700{ }^{\circ} \mathrm{C}$ in $50{ }^{\circ} \mathrm{C}$ increments, the char yield decreased sharply from $57.09 \%$ to $20.39 \%$, while the gas yield rose dramatically from $16.25 \%$ to $41.33 \%$. In particular, the bio-oil yield did not display monotonic trends with the increasing temperature. The bio-oil yield achieved the maximum of $54.97 \%$ at the final pyrolysis temperature of $500{ }^{\circ} \mathrm{C}$.

The decrease of the bio-oil yield at higher pyrolysis temperatures is due to the secondary reactions that, in parallel cause the increase in of the gas yield. The decrease of the bio-char yield with increasing temperature may be attributed to either a greater primary decomposition of the raw material at higher temperatures or to the secondary decomposition of the solid product, leading to an increase of the pyrolysis conversion. The yield of non-condensable gas products increases due to the secondary decomposition of the bio-char at higher temperatures, which also contribute to the increasing of the gas products yield with increasing temperature (Onay, 2007; Onay and Koçkar, 2006, 2004; Rahman et al., 2014).

The rest of this study, only bio-oil and bio-char that were obtained under the most suitable conditions, a temperature of $500{ }^{\circ} \mathrm{C}$ and a heating rate of $10{ }^{\circ} \mathrm{C} / \mathrm{min}$ were retained for next characterization.

\subsection{Bio-oil characterization}

\subsubsection{Elemental composition and ash content}

The ultimate analysis, proximate analysis and calorific value of the bio-oil are shown in Table 1. As can be seen, the bio-oil has a high carbon (51.12\%) content and a low oxygen content $(37.20 \%)$ content, whereas there is a slight increase in the hydrogen 
(5.81\%) content compared to the raw algal waste $(35.27 \%, 54.85 \%$ and $4.71 \%$, respectively). The results show an increase in HHV and a decrease of the $\mathrm{H} / \mathrm{C}$ molar ratio of the bio-oil compared to the raw material. The average chemical composition of the bio-oil is $\mathrm{CH}_{1,364} \mathrm{O}_{1,546} \mathrm{~N}_{0,078}$.

\subsubsection{FTIR characterization}

The bio-oil was analyzed by FTIR spectroscopy (Figure 2), the functional groups and related classification of compounds were listed in Table 2 . The absorption peak at 3200$3600 \mathrm{~cm}^{-1}$ indicated the presence of oxygenated compounds (O-H group). The presence of methyl and methylene groups (alkanes, alkenes) is indicated by the intense peak of C-H stretching vibrations between 2800 and $3000 \mathrm{~cm}^{-1}$ (tree peat at 2852, 2925 and $2960 \mathrm{~cm}^{-1}$ ) and by C-H deformation vibrations between 1350 and $1475 \mathrm{~cm}^{-1}$ (tree peaks at 1376,1411 and $1452 \mathrm{~cm}^{-1}$ ) (Francavilla et al., 2015). The $\mathrm{C}=\mathrm{O}$ deformation vibrations with absorbance at $1700 \mathrm{~cm}^{-1}$ indicate the presence of ketones, carboxylic acid or aldehydes groups. The intense peak $1656 \mathrm{~cm}^{-1}$ represents $\mathrm{C}=\mathrm{C}$ stretching vibrations, which is indicative of alkenes. In addition, the absorbance peaks at 1730$1150 \mathrm{~cm}^{-1}$, corresponding to the presence of heteroatoms (i.e. $\mathrm{N}$ and $\mathrm{O}$ ) functionality, were also observed, which was consistent with results of the GC-MS analysis presented in Table 3. The peaks appear in the range of $1475-1525 \mathrm{~cm}^{-1}$ and 700 and $900 \mathrm{~cm}^{-1}$, attributable to the aromatic stretching vibrations, indicating the presence of aromatic compounds in bio-oil. Moreover, the acid compounds are represented by the C-O stretching peaks observed between $1210 \mathrm{~cm}^{-1}$ and $1320 \mathrm{~cm}^{-1}$. The peaks between 1000 and $1200 \mathrm{~cm}^{-1}$ are due to the presence of alcohols, phenols, ethers and esters showing the $\mathrm{C}-\mathrm{O}$ stretching vibrations. 


\subsubsection{Chemical composition (GC/MS)}

GC-MS analysis was carried out in order to determine the component of organic compounds in the bio-oil produced at the optimum pyrolysis conditions. As can be seen in Figure 4, bio-oil produced from algal waste is a very complex mixture, and more than 200 compounds were detected in the bio-oil. When mass spectra were compared to the NIST library data, 30 compounds with more than $1.5 \%$ of the total area (defined by the percentage of the compound's chromatographic area out of the total area) were identified; the results is presented in Table 3. The bio-oil from algal waste pyrolysis was composed of a very complex mixture of organic compounds of 5-20 carbons. It can be seen that the bio-oil was mainly composed of phenols, acids, alkanes, furans, ketones, and alcohols and nitrogen-containing heterocycles (indoles and pyridines). The components of the bio-oil were similar to the liquid product obtained by other researchers (Ferrera-Lorenzo et al., 2014b; Ross et al., 2008). The most abundant compound Phenols accounted for $24.79 \%$. These derivatives of phenolic fragments might be derived from the thermal decomposition of protein, which are known as the polyphenolic components in aquatic biomass (Ross et al., 2008). Different types of acids and alkanes were identified, and they mostly converted from carbohydrates degradation. The nitrogen-containing heterocyclic compounds in algal bio-oils, such as indoles and pyridines, were assumed to be derived from protein degradation (Zhou et al., 2010). Among the compositions of bio-oil, Phenol (8.82 area \%), Phenol 4-methyl(13.47 area \%), Heptadecane (5.12 area \%), n-Hexadecanoic acid (10.96 area \%), Hexadecanamide (4.41 area \%) showed the highest selectivity. This result is consistent with the FTIR result of bio-oil. 


\subsection{4. ${ }^{1} H-R M N$ characterization}

To have a clearer understanding of the compound distribution of the whole bio-oil, an analysis was carried out using ${ }^{1} \mathrm{H}-\mathrm{NMR}$. NMR spectra provided complementary functional group information to the FTIR spectrum and the ability to quantify integration areas. The ${ }^{1} \mathrm{H}-\mathrm{NMR}$ spectrum of the bio-oil is shown in Figure 5. The percentages of the proton types that were calculated on the basis of the chemical deviation values obtained from the ${ }^{1} \mathrm{H}-\mathrm{NMR}$ spectra are in Table 4. The most up-field region from 0.5 to $1.5 \mathrm{ppm}$, represented aliphatic protons that were attached to carbon atoms, at least two bonds, removed from a $\mathrm{C}=\mathrm{C}$ double bond or heteroatom $(\mathrm{O}$ or $\mathrm{N})$. This region contains $32.31 \%$ of the protons in bio-oil. The next integral region from 1.5 to $3.0 \mathrm{ppm}$ represents protons of aliphatic carbon atoms that may be bonded to a $\mathrm{C}=\mathrm{C}$ double bond (aromatic or olefinic) or are two bonds away from a heteroatom (O or N). These protons contribute with $29.61 \%$ of the protons in the bio-oil. The typical compounds with these functional groups in the region $0.5-3.0 \mathrm{ppm}$ were confirmed by GC/MS and FTIR. The region in 3.0-4.5 ppm contributes $5.99 \%$ of the protons in biooil, which represent protons on carbon atoms next to an aliphatic alcohol and nitrogen connected to methylene groups. The region 4.5 and $6.0 \mathrm{ppm}$ represents aromatic ether proton and many of the hydrogen atoms of carbohydrate-like molecules. The value of proton percentage was $6.64 \%$. The region of the spectrum between 6.0 and $9.5 \mathrm{ppm}$ corresponds to the aromatic portons, aldehyde protons, and also those in heteroaromatics containing oxygen and nitrogen and the content of this region was $25.45 \%$. The bio-oil produced by pyrolysis cannot be used as fuel due to its high water and oxygen contents and the presence of unsaturated and phenolic compounds. As a result, 
bio-oil need to be upgraded or pre-treated to improve their quality before being used as bio-fuel. The compounds identified in the bio-oil from waste algal suggest that pyrolysis can be used to produce bio-oil for various uses, such as in the petrochemical industry and as high added value chemicals, through further treatment.

\subsection{Bio-char characterization}

\subsubsection{Elemental composition and ash content}

The ultimate analysis, proximate analysis and calorific value of bio-char from the pyrolysis of algal waste are listed in Table 1 . The bio-char have high carbon content $(52.95 \%)$, moderate oxygen content $(38.00 \%)$, low hydrogen content $(2.83 \%)$ and high nitrogen content $(6.22 \%)$. The ash content is high (around 31,52\%). In comparison to the raw algal waste, the $\mathrm{O}$ and $\mathrm{H}$ contents decrease in the bio-char due to dehydration, decarbonylation and decarboxylation reactions, which is consistent with the FTIR results. The hydrogen content decreases in the bio-char, probably due to the aromatization of the bio-char and evolution of $\mathrm{H}_{2}$, as light molecular hydrocarbons $\left(\mathrm{CH}_{4}\right.$ and $\mathrm{C}_{2}$ ) were formed during the pyrolysis process. The carbon content and HHV make the bio-char from pyrolysis of algal waste acceptable for use as a renewable solid fuel.

\subsubsection{FTIR characterization}

The bio-char from pyrolysis of algal waste was also characterized by FTIR (figure 2). Remarkable changes have been found for the FTIR spectra of Bio-char (Figure 2) compared to that of the raw material, which indicated an effective conversion of the waste algal under pyrolysis conditions (temperature of $500{ }^{\circ} \mathrm{C}$ and heating rate of 10 ${ }^{\circ} \mathrm{C} / \mathrm{min}$ ). The $\mathrm{O}-\mathrm{H}$ stretching vibration at $3600-3100 \mathrm{~cm}^{-1}$ in the FTIR spectra of the bio- 
char sharply decreased after pyrolysis, probably due to the dehydration of the waste algal together with the release of an amount of water. The bands occurring at 2860-2970 $\mathrm{cm}^{-1}$, which can be assigned to the $\mathrm{C}-\mathrm{H}$ alkyl functional groups, were almost absent in the bio-char. The peaks between 1900 and $2300 \mathrm{~cm}^{-1}$ indicate carboxyl and carbonyl groups. Strong peaks which are representative of aromatic $\mathrm{C}=\mathrm{O}$ and $\mathrm{C}=\mathrm{C}$ functional groups at $1400 \mathrm{~cm}^{-1}$ as well as a peak at $875 \mathrm{~cm}^{-1}$ which correlates with aromatic $\mathrm{C}-\mathrm{H}$ stretching. A wide band from 900 to $1200 \mathrm{~cm}^{-1}$ shows aromatic C-O and phenolic O-H functional groups. The peaks between 700 and $900 \mathrm{~cm}^{-1}$ was assigned to aromatic C-H stretching vibrations that indicate the presence of adjacent aromatic hydrogens in biochar. Similar to the results obtained by the Zhou et al. (2010).

The spectrum of bio-char from waste algal suggests the presence of a variety of oxygen functional groups, as well as aromatic carbon groups (bio-char was mainly an aromatic polymer carbon atom). The spectrum correlates well with the elemental analysis, which also revealed a relatively high amount of retained oxygen content.

\subsubsection{Scanning electron microscopy}

The morphology of raw waste and its bio-char has been studied by scanning electron microscopy (SEM). The obtained photographs for raw waste and its bio-char are shown in Figure 6. From these micrographs, it is clear that the raw waste and its bio-char show different behaviours regarding their morphologies. The morphology of the bio-char shows more void space and higher porosity on its surface, confirming that the produced bio-char has a higher surface area than the raw waste material. This can be attributed to the fact that thermal treatment improves the porous structure of bio-char due to the loss of mass of part of volatiles from the starting algal waste leaving the skeletal structure. 


\section{Conclusion}

In this study, the algal waste had been converted to bio-oil and bio-char by pyrolysis. The maximum yields of bio-oil and bio-char were approximately 24.1 and $44.01 \mathrm{wt} \%$, respectively, at the pyrolysis temperature was $500{ }^{\circ} \mathrm{C}$ for heating rate of $10{ }^{\circ} \mathrm{C} / \mathrm{min}$. The bio-oil was composed of phenols, acids, alkanes, furans, ketones, and alcohols and nitrogen-containing heterocycles. This preliminary study has shown that the bio-oil cannot be used as bio-fuel, but can be potentially used as a source of value-added chemicals. In addition, the bio-char shows good properties as a solid fuel and as a carbon source for producing carbon materials.

\section{Acknowledgements}

The authors would like to thank Pr. Alami Jones, head of MSN department for his valuable assistance for improving the manuscript. The authors gratefully acknowledge the SETEXAM Company in Morocco for providing the algal waste. This work is the result of collaboration between the Faculté polydisciplinaire de Béni-Mellal (Université Sultan Moulay Slimane), INRA Montpellier and the Materials Science and Nanoengineering Department (Mohamed 6 Polytechnic University). 


\section{References}

Ainane, T., 2011. Valuation Algal biomass of Morocco :Potential pharmacological and Environmental Applications, case of the brown algae Cystoseira tamariscifolia and Bifurcaria bifurcate. Thesis, Faculty of Sciences Ben M'sik, Hassan II University Casablanca, Morocco.

Bae, Y.J., Ryu, C., Jeon, J.-K., Park, J., Suh, D.J., Suh, Y.-W., Chang, D., Park, Y.-K., 2011. The characteristics of bio-oil produced from the pyrolysis of three marine macroalgae. Bioresour. Technol. 102, 3512-3520.

Ben Hassen-Trabelsi, A., Kraiem, T., Naoui, S., Belayouni, H., 2014. Pyrolysis of waste animal fats in a fixed-bed reactor: Production and characterization of bio-oil and bio-char. Waste Manag. 34, 210-218.

Chaiwong, K., Kiatsiriroat, T., n.d. Characterizations of Bio-oil and Bio-char Products from Algae with Slow and Fast Pyrolysis. Int. J. Environ. Bioenergy 10, 65-76.

Chen, J., Fan, X., Jiang, B., Mu, L., Yao, P., Yin, H., Song, X., 2015. Pyrolysis of oilplant wastes in a TGA and a fixed-bed reactor: Thermochemical behaviors, kinetics, and products characterization. Bioresour. Technol. 192, 592-602.

Choi, J.H., Kim, S.-S., Suh, D.J., Jang, E.-J., Min, K.-I., Woo, H.C., 2016.

Characterization of the bio-oil and bio-char produced by fixed bed pyrolysis of the brown alga Saccharina japonica. Korean J. Chem. Eng. 33, 2691-2698.

Demiral, İ., Eryazıcı, A., Şensöz, S., 2012. Bio-oil production from pyrolysis of corncob (Zea mays L.). Biomass Bioenergy 36, 43-49.

Demirbas, M.F., 2011. Biofuels from algae for sustainable development. Appl. Energy $88,3473-3480$. 
Ennouali, M., Ouhssine, M., Ouhssine, K., Elyachioui, M., 2006. Biotransformation of algal waste by biological fermentation. Afr. J. Biotechnol. 5, 1233-1237.

Ertaş, M., Hakk1 Alma, M., 2010. Pyrolysis of laurel (Laurus nobilis L.) extraction residues in a fixed-bed reactor: Characterization of bio-oil and bio-char. J. Anal. Appl. Pyrolysis 88, 22-29.

Ferrera-Lorenzo, N., Fuente, E., Bermúdez, J.M., Suárez-Ruiz, I., Ruiz, B., 2014a. Conventional and microwave pyrolysis of a macroalgae waste from the AgarAgar industry. Prospects for bio-fuel production. Bioresour. Technol. 151, 199206.

Ferrera-Lorenzo, N., Fuente, E., Suárez-Ruiz, I., Gil, R.R., Ruiz, B., 2014b. Pyrolysis characteristics of a macroalgae solid waste generated by the industrial production of Agar-Agar. J. Anal. Appl. Pyrolysis 105, 209-216.

Francavilla, M., Manara, P., Kamaterou, P., Monteleone, M., Zabaniotou, A., 2015. Cascade approach of red macroalgae Gracilaria gracilis sustainable valorization by extraction of phycobiliproteins and pyrolysis of residue. Bioresour. Technol. $184,305-313$.

Hanif, N., Idrissi, M.C., Naoki, T., others, 2014. The exploitation of red algae Gelidium in the region of El-Jadida : socio-economic aspects and perspectives. Afr. Sci. Rev. Int. Sci. Technol. 10, 103-126.

Hu, Z., Zheng, Y., Yan, F., Xiao, B., Liu, S., 2013. Bio-oil production through pyrolysis of blue-green algae blooms (BGAB): Product distribution and bio-oil characterization. Energy 52, 119-125. 
Kim, S.-S., Ly, H.V., Kim, J., Choi, J.H., Woo, H.C., 2013. Thermogravimetric characteristics and pyrolysis kinetics of Alga Sagarssum sp. biomass. Bioresour. Technol. 139, 242-248.

Kraiem, T., Hassen-Trabelsi, A.B., Naoui, S., Belayouni, H., Jeguirim, M., 2015. Characterization of the liquid products obtained from Tunisian waste fish fats using the pyrolysis process. Fuel Process. Technol. 138, 404-412.

Li, D., Chen, L., Xu, D., Zhang, X., Ye, N., Chen, F., Chen, S., 2012. Preparation and characteristics of bio-oil from the marine brown alga Sargassum patens C. Agardh. Bioresour. Technol. 104, 737-742.

Maddi, B., Viamajala, S., Varanasi, S., 2011. Comparative study of pyrolysis of algal biomass from natural lake blooms with lignocellulosic biomass. Bioresour. Technol. 102, 11018-11026.

Mouradi-Givernaud, A., Hassani, L.A., Givernaud, T., Lemoine, Y., Benharbet, O., 1999. Biology and agar composition of Gelidium sesquipedale harvested along the Atlantic coast of Morocco. Hydrobiologia 398-399, 391-395.

Nanda, S., Isen, J., Dalai, A.K., Kozinski, J.A., 2016. Gasification of fruit wastes and agro-food residues in supercritical water. Energy Convers. Manag. 110, 296306.

Norouzi, O., Jafarian, S., Safari, F., Tavasoli, A., Nejati, B., 2016. Promotion of hydrogen-rich gas and phenolic-rich bio-oil production from green macroalgae Cladophora glomerata via pyrolysis over its bio-char. Bioresour. Technol. 219, 643-651. 
Onay, O., 2007. Influence of pyrolysis temperature and heating rate on the production of bio-oil and char from safflower seed by pyrolysis, using a well-swept fixedbed reactor. Fuel Process. Technol. 88, 523-531.

Onay, O., Koçkar, O.M., 2006. Pyrolysis of rapeseed in a free fall reactor for production of bio-oil. Fuel 85, 1921-1928.

Onay, O., Koçkar, O.M., 2004. Fixed-bed pyrolysis of rapeseed (Brassica napus L.). Biomass Bioenergy 26, 289-299.

Rahman, A.A., Abdullah, N., Sulaiman, F., 2014. Temperature effect on the characterization of pyrolysis products from oil palm fronds. Adv. Energy Eng. 2, $14-21$.

Ross, A.B., Jones, J.M., Kubacki, M.L., Bridgeman, T., 2008. Classification of macroalgae as fuel and its thermochemical behaviour. Bioresour. Technol. 99, 6494-6504.

Saldarriaga, J.F., Aguado, R., Pablos, A., Amutio, M., Olazar, M., Bilbao, J., 2015. Fast characterization of biomass fuels by thermogravimetric analysis (TGA). Fuel $140,744-751$.

Yanik, J., Stahl, R., Troeger, N., Sinag, A., 2013. Pyrolysis of algal biomass. J. Anal. Appl. Pyrolysis 103, 134-141.

Zhao, H., Yan, H., Dong, S., Zhang, Y., Sun, B., Zhang, C., Ai, Y., Chen, B., Liu, Q., Sui, T., Qin, S., 2013. Thermogravimetry study of the pyrolytic characteristics and kinetics of macro-algae Macrocystis pyrifera residue. J. Therm. Anal. Calorim. 111, 1685-1690.

Zhao, H., Yan, H.-X., Liu, M., Sun, B.-B., Zhang, Y., Dong, S.-S., Qi, L.-B., Qin, S., 2013. Production of bio-oil from fast pyrolysis of macroalgae enteromorpha 
prolifera powder in a free-fall reactor. Energy Sources Part Recovery Util. Environ. Eff. 35, 859-867.

Zhou, D., Zhang, L., Zhang, S., Fu, H., Chen, J., 2010. Hydrothermal liquefaction of macroalgae Enteromorpha prolifera to bio-oil. Energy Fuels 24, 4054-4061.

Zou, S., Wu, Y., Yang, M., Li, C., Tong, J., 2009. Thermochemical Catalytic

Liquefaction of the Marine Microalgae Dunaliella tertiolecta and

Characterization of Bio-oils. Energy Fuels 23, 3753-3758. 


\section{List of Figures:}

Figure 1: TGA/DTG of algal waste.

Figure 2: FTIR spectrum of algal waste, its bio-oil and bio-char obtained at $500^{\circ} \mathrm{C}$ for $10^{\circ} \mathrm{C} / \mathrm{min}$.

Figure 3: a) The effect of final temperature on pyrolysis products distribution for a heating rate of $\left.10^{\circ} \mathrm{C} / \mathrm{min}, \mathrm{b}\right)$ The effect of heating rate on pyrolysis products distribution at final temperature of $500^{\circ} \mathrm{C}$.

Figure 4: GC/MS spectrum of bio-oil obtained at $500^{\circ} \mathrm{C}$ for $10^{\circ} \mathrm{C} / \mathrm{min}$.

Figure 5: ${ }^{1} \mathrm{H}-\mathrm{NMR}$ spectrum of bio-oil obtained at $500^{\circ} \mathrm{C}$ for $10^{\circ} \mathrm{C} / \mathrm{min}$.

Figure 6: SEM micrograph of the algal waste (a) and its bio-char (b). 


\section{List of Tables:}

Table 1: Proximate and ultimate analysis of algal waste, bio-oil and bio-char.

Table 2: FTIR bands and functional groups of bio-oil obtained at $500^{\circ} \mathrm{C}$ for $10^{\circ} \mathrm{C} / \mathrm{min}$.

Table 3: Chemical composition of bio-oil obtained at $500^{\circ} \mathrm{C}$ for $10^{\circ} \mathrm{C} / \mathrm{min}$ from GC/MS.

Table 4: ${ }^{1} \mathrm{H}-\mathrm{NMR}$ analysis results of bio-oil obtained at $500^{\circ} \mathrm{C}$ for $10^{\circ} \mathrm{C} / \mathrm{min}$. 
Figure 1

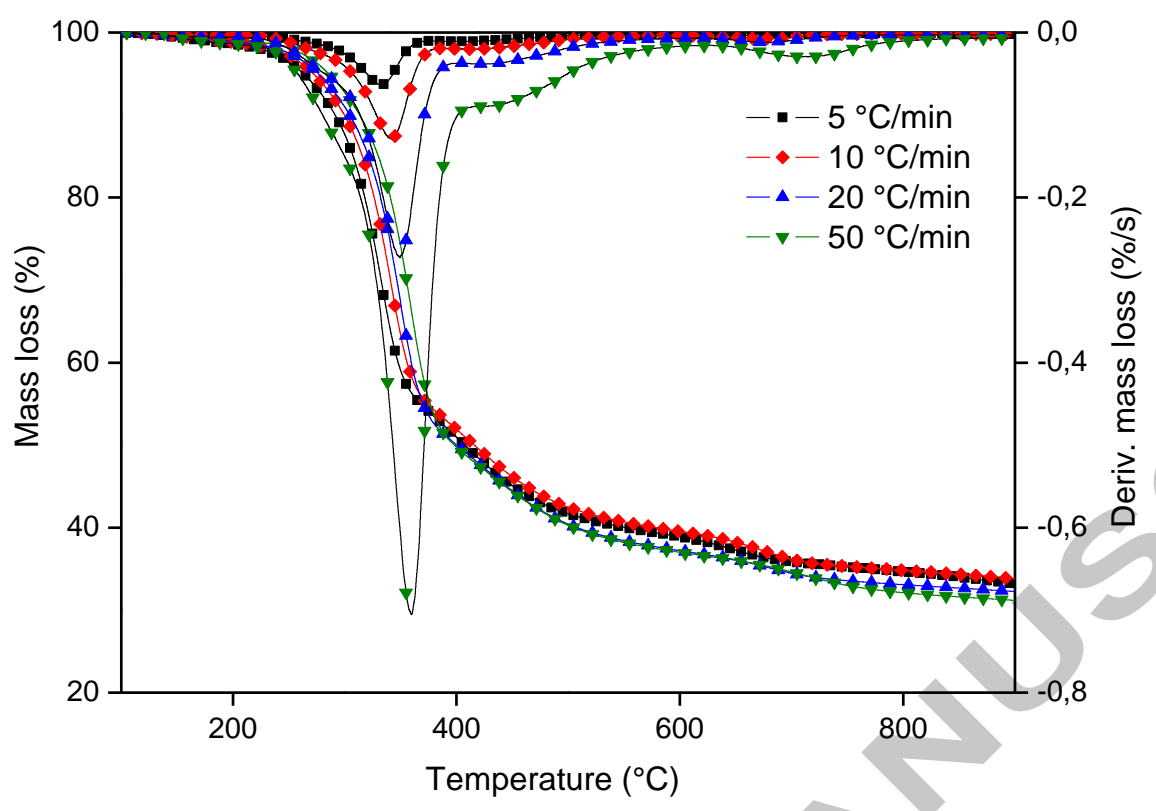

Figure 2

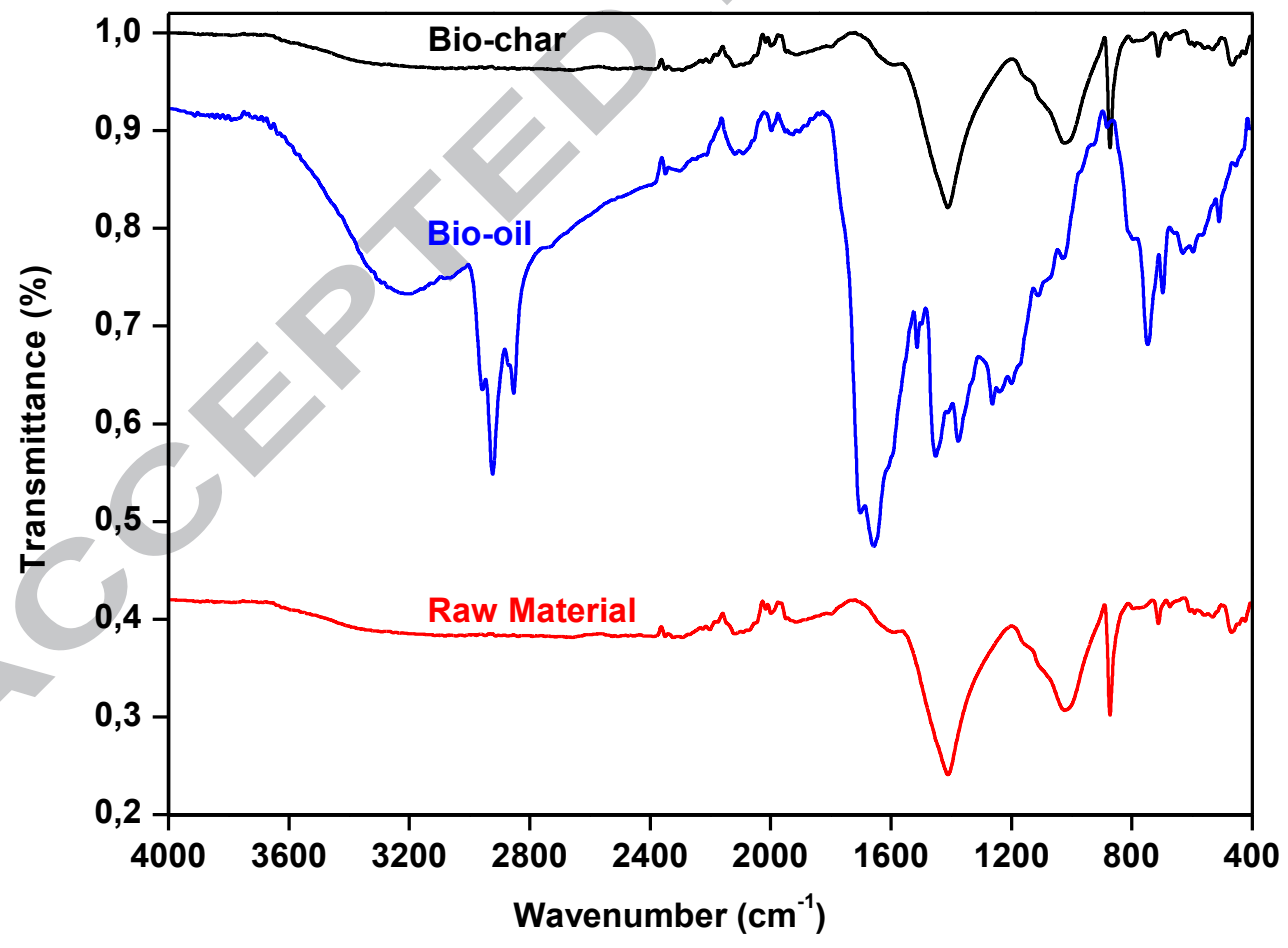


Figure 3:
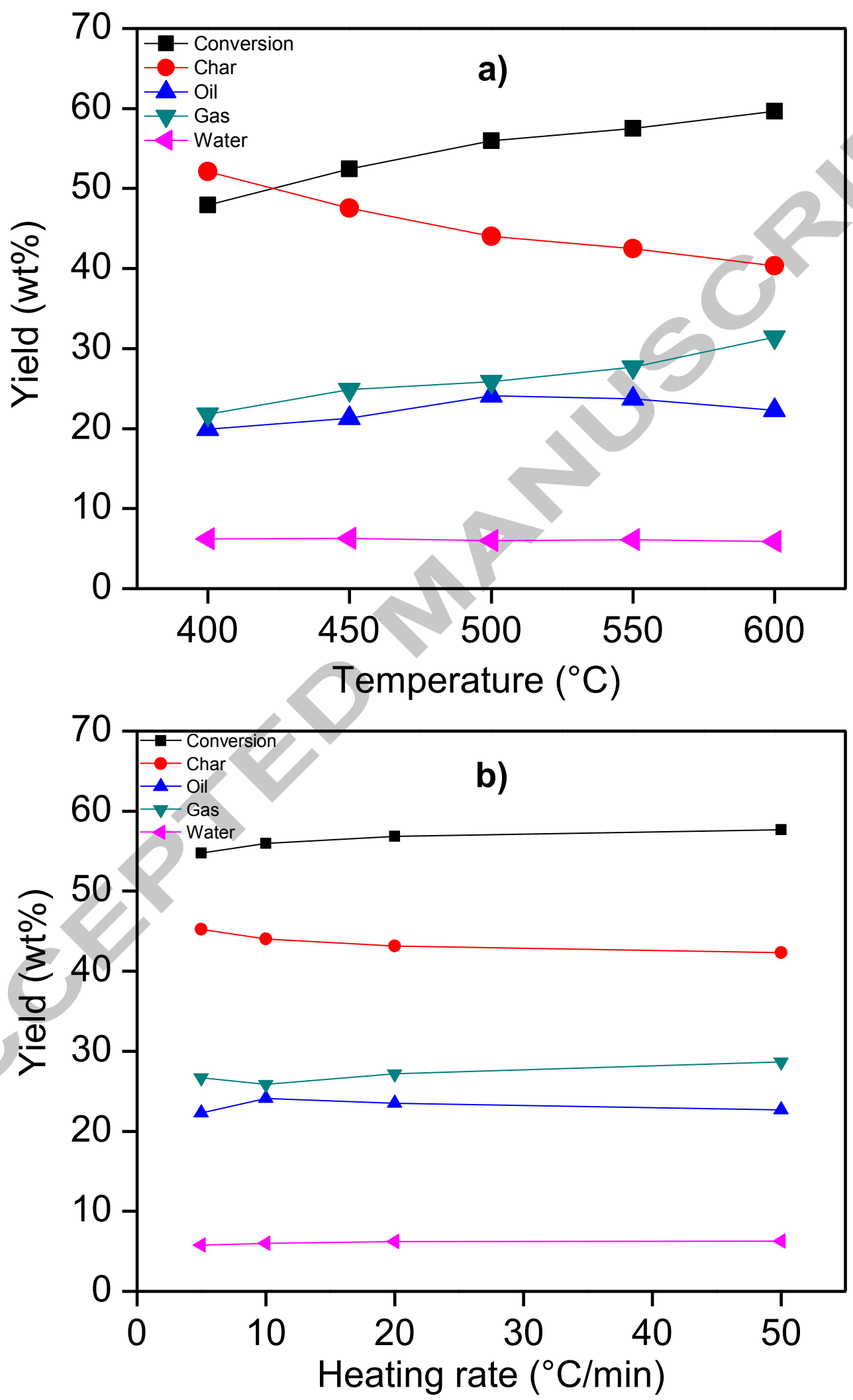
Figure 4

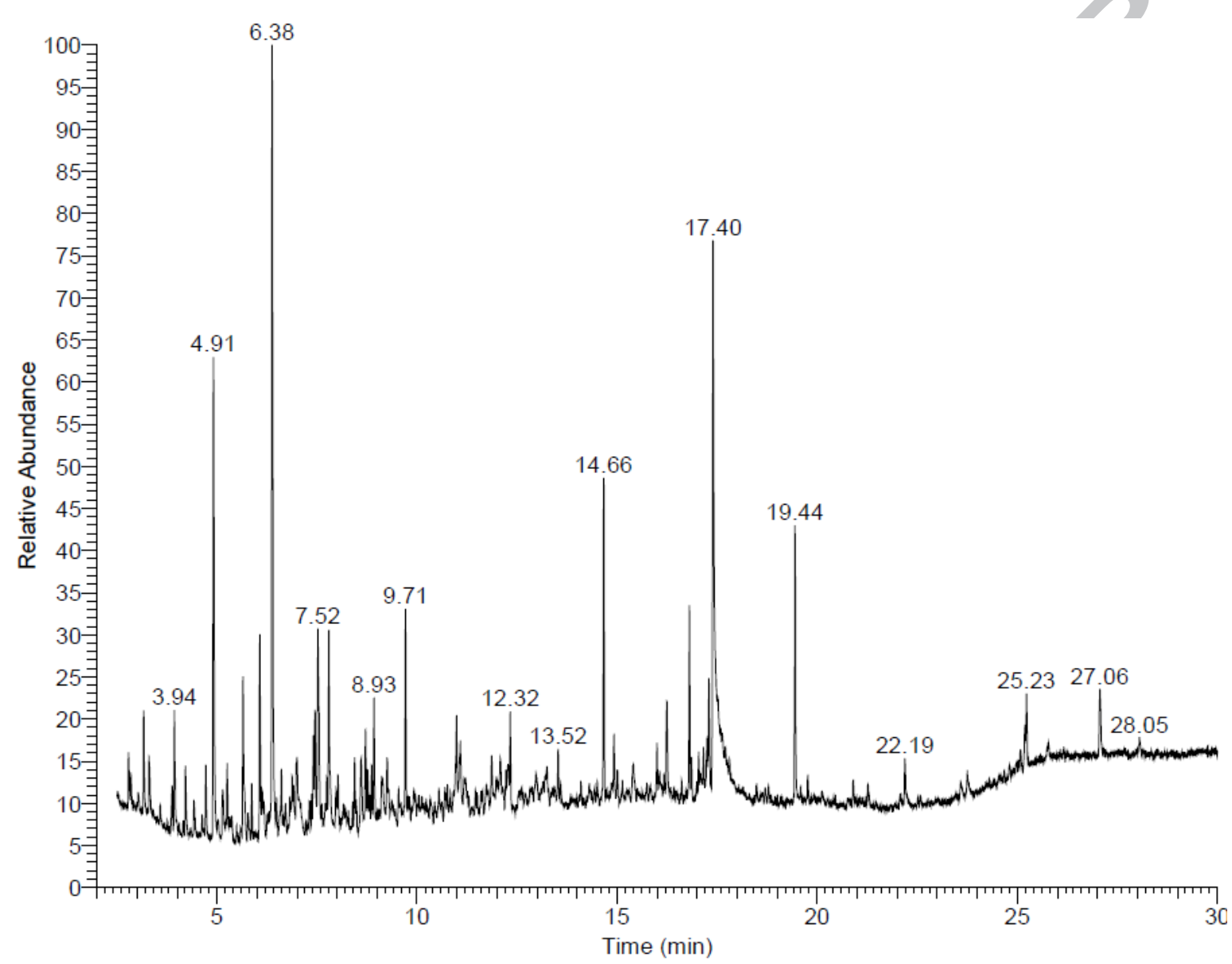


Figure 5

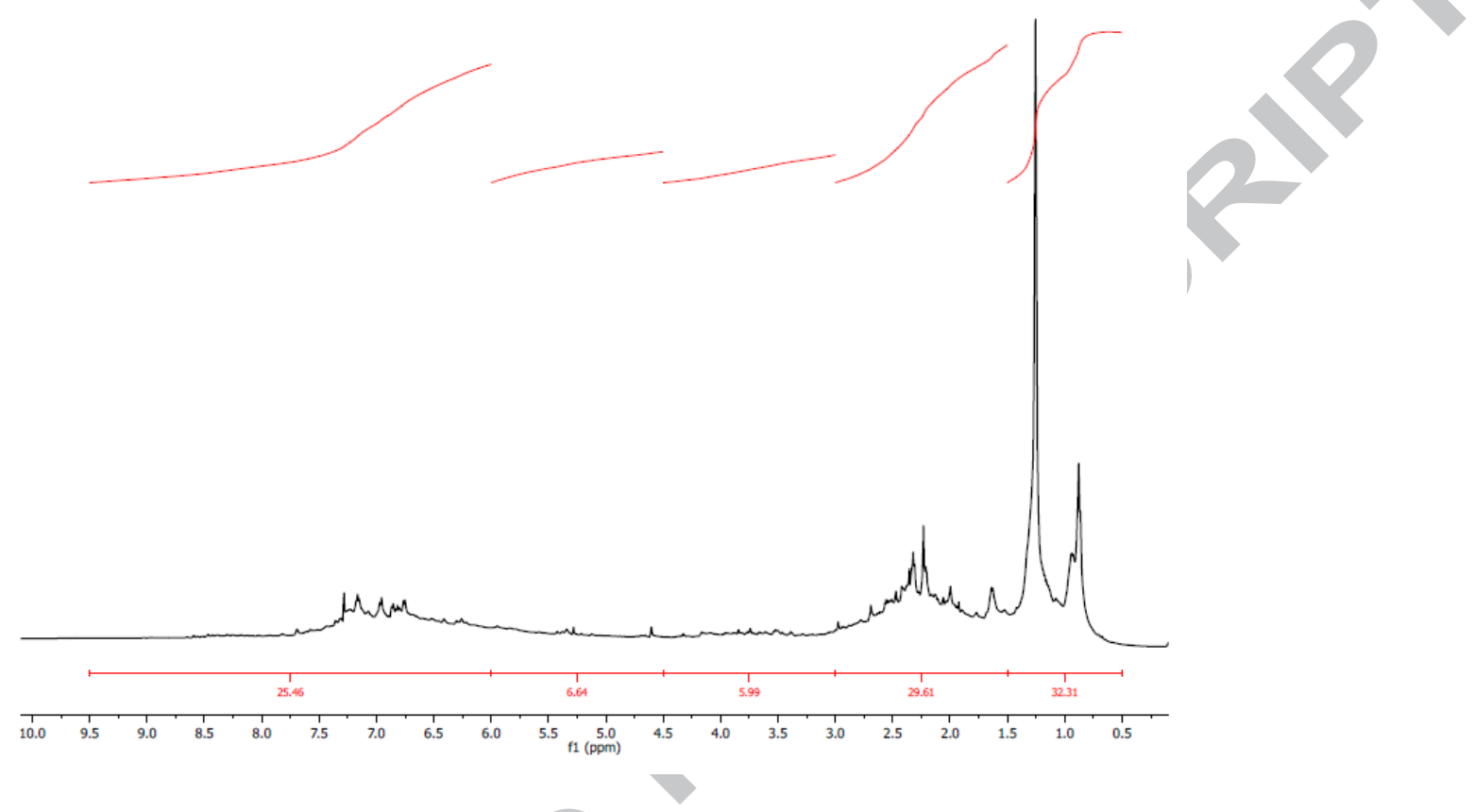

Figure 6

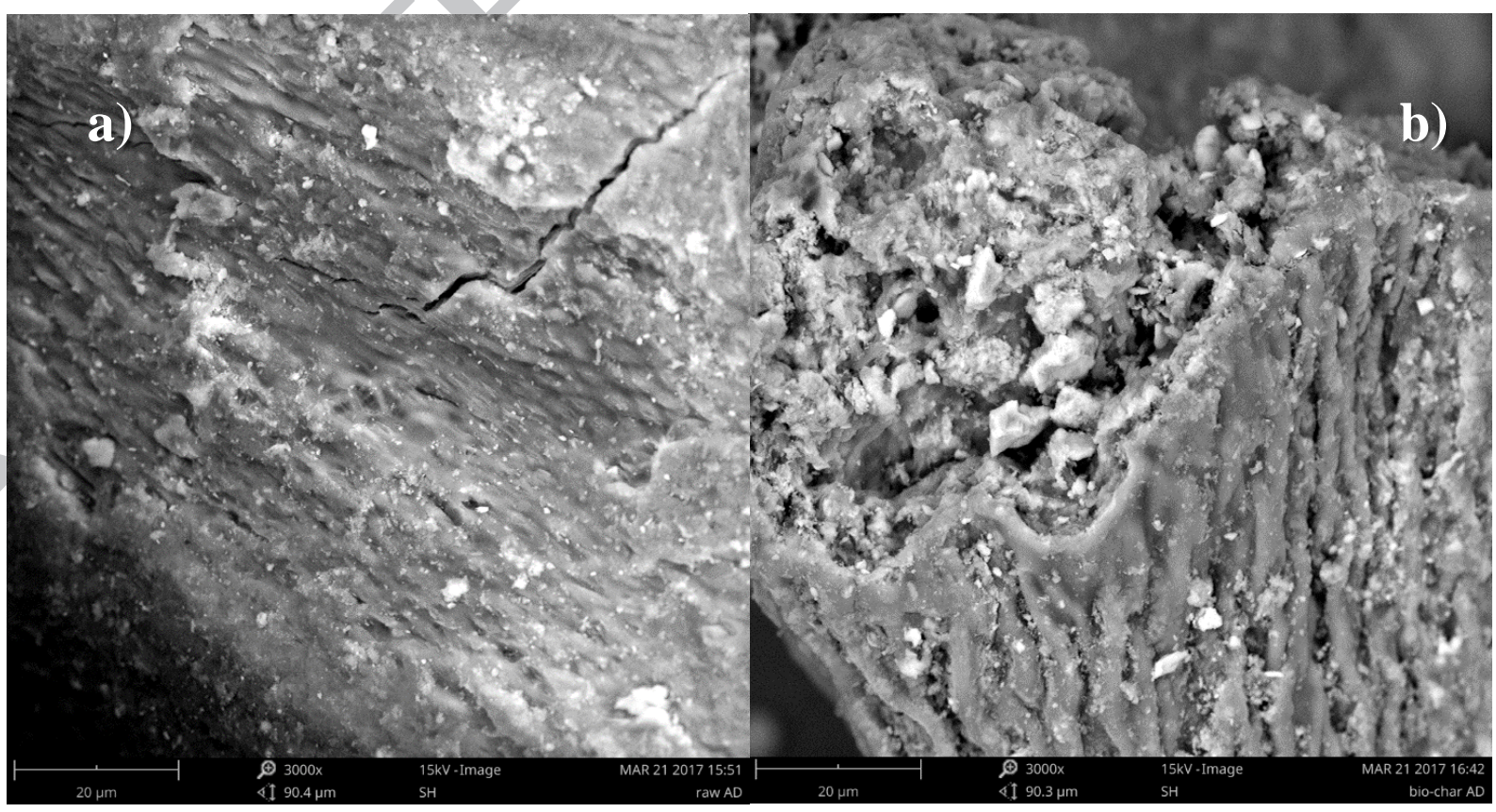


Table 1:

\begin{tabular}{|c|c|c|c|c|}
\hline & & algal waste & Bio-oil & Bio-char \\
\hline \multirow[t]{4}{*}{$\begin{array}{c}\text { Proximate } \\
\text { analysis } \\
\text { (wt.\%) }\end{array}$} & Moisture & 5.04 & 14.22 & 4,05 \\
\hline & Volatile matter & 68.91 & 86,75 & 24,70 \\
\hline & Ash & 12.09 & 1,7 & 31,52 \\
\hline & Fixed carbon & 19.00 & 11,55 & 43,78 \\
\hline \multirow[t]{5}{*}{$\begin{array}{l}\text { Ultimate } \\
\text { analysis } \\
\text { (wt.\%) }\end{array}$} & $\mathrm{C}$ & 35.27 & 51,12 & 52,95 \\
\hline & $\mathrm{H}$ & 4.71 & 5,81 & 2,83 \\
\hline & $\mathrm{N}$ & 4.44 & 4,68 & 6,22 \\
\hline & $S$ & 0.73 & 1,19 & -- \\
\hline & $\mathrm{O}$ & 54,85 & 37,2 & 38.00 \\
\hline $\begin{array}{c}\mathrm{HHV} \\
(\mathrm{MJ} / \mathrm{kg})\end{array}$ & & 14.98 & 19.91 & 23.09 \\
\hline \multirow[t]{2}{*}{ Atomic } & $\mathrm{H} / \mathrm{C}$ & 1,603 & 1.364 & 0.639 \\
\hline & $\mathrm{O} / \mathrm{C}$ & 1.166 & 0.546 & 0.538 \\
\hline $\begin{array}{c}\text { Empirical } \\
\text { formula }\end{array}$ & & $\mathrm{CH}_{1,603} \mathrm{O}_{1,166} \mathrm{~N}_{0,108}$ & $\mathrm{CH}_{1,364} \mathrm{O}_{1,546} \mathrm{~N}_{0,078}$ & $\mathrm{CH}_{0,639} \mathrm{O}_{0,538} \mathrm{~N}_{0,101}$ \\
\hline
\end{tabular}

Table 2:

\begin{tabular}{|c|c|c|c|}
\hline $\begin{array}{c}\text { Frequency range, } \mathrm{cm}_{1}^{-} \\
3300-3600\end{array}$ & Frequency, $\mathrm{cm}^{-1}$ & Group & Class of Compound \\
\hline $3050-2800$ & 3230 & O-H stretching & Polymeric O-H \\
\hline $1690-1750$ & 1700 & C=O stretching & $\begin{array}{c}\text { Ketones, aldehydes, } \\
\text { carboxylic acids }\end{array}$ \\
\hline $1570-1680$ & 1656 & C=C stretching & Alkenes \\
\hline $1475-1525$ & 1515 & C=Cring stretching & Aromatics \\
\hline $1475-1330$ & $1390,1411,1450$ & C-H deformation & Alkanes \\
\hline $1280-1200$ & 1260,1240 & C-H stretching & Aromatics \\
\hline $1000-1200$ & $1026,1110,1195$ & C-O stretching & $\begin{array}{c}\text { Alcohols, esters, } \\
\text { ethers }\end{array}$ \\
\hline 885 & 885 & C-H deformation & Aromatics \\
\hline 750 & 750 & $\begin{array}{c}\text { Adjacent C-H } \\
\text { deformation }\end{array}$ & Aromatics \\
\hline 696 & 696 & $\begin{array}{c}\text { Out of plan }=\mathrm{CH} \\
\text { deformation }\end{array}$ & Alkenes \\
\hline 615 & 615 & $\begin{array}{c}\text { Out of plan O-H } \\
\text { deformation }\end{array}$ & Polymeric O-H \\
\hline
\end{tabular}


Table 3:

\begin{tabular}{|c|c|c|c|c|}
\hline $\mathrm{N}^{\circ}$ & $\begin{array}{l}\text { Retention } \\
\text { time (min) }\end{array}$ & Compounds & $\begin{array}{l}\text { Molecular } \\
\text { formula }\end{array}$ & $\begin{array}{c}\text { Area } \\
(\%)\end{array}$ \\
\hline 1 & 3,17 & 2-Furanmethanol & $\mathrm{C}_{5} \mathrm{H}_{6} \mathrm{O}_{2}$ & 1,73 \\
\hline 2 & 3,94 & Ethanone, 1-(2-furanyl)- & $\mathrm{C}_{6} \mathrm{H}_{6} \mathrm{O}_{2}$ & 2,24 \\
\hline 3 & 4,91 & Phenol & $\mathrm{C}_{6} \mathrm{H}_{6} \mathrm{O}$ & 8,82 \\
\hline 4 & 5,65 & $\begin{array}{l}\text { 2-Cyclopenten-1-one, 2-hydroxy- } \\
\text { 3-methyl- } \\
\end{array}$ & $\mathrm{C}_{6} \mathrm{H}_{8} \mathrm{O}_{2}$ & 3,2 \\
\hline 5 & 6,07 & Phenol, 2-methyl- & $\mathrm{C}_{7} \mathrm{H}_{8} \mathrm{O}$ & 3,67 \\
\hline 6 & 6,13 & $\begin{array}{l}\text { (3S,4R,5R,6R)-4,5- } \\
\text { Bis(hydroxymethyl)-3,6- } \\
\text { dimethylcyclohexene }\end{array}$ & $\mathrm{C}_{10} \mathrm{H}_{18} \mathrm{O}_{2}$ & 1,66 \\
\hline 7 & 6,38 & Phenol, 4-methyl- & $\mathrm{C}_{7} \mathrm{H}_{8} \mathrm{O}$ & 13,47 \\
\hline 8 & 6,61 & 2,5-Pyrrolidinedione, 1-methyl- & $\mathrm{C}_{5} \mathrm{H}_{7} \mathrm{NO}_{2}$ & 1,37 \\
\hline 9 & 6,88 & $\begin{array}{l}\text { 2,4-Imidazolidinedione, 3,5,5- } \\
\text { trimethyl- }\end{array}$ & $\mathrm{C}_{6} \mathrm{H}_{10} \mathrm{~N}_{2} \mathrm{O}_{2}$ & 1,51 \\
\hline 10 & 7 & Maltol & $\mathrm{C}_{6} \mathrm{H}_{6} \mathrm{O}_{3}$ & 2,97 \\
\hline 11 & 7,45 & Glutarimide & $\mathrm{C}_{5} \mathrm{H}_{7} \mathrm{NO}_{2}$ & 2,8 \\
\hline 12 & 7,52 & Phenol, 2,4-dimethyl- & $\mathrm{C}_{8} \mathrm{H}_{10} \mathrm{O}$ & 4,26 \\
\hline 13 & 7,8 & Phenol, 4-ethyl- & $\mathrm{C}_{8} \mathrm{H}_{10} \mathrm{O}$ & 3,39 \\
\hline 14 & 8,44 & $\begin{array}{l}\text { 1,4:3,6-Dianhydro-à-d- } \\
\text { glucopyranose }\end{array}$ & $\mathrm{C}_{6} \mathrm{H}_{8} \mathrm{O}_{4}$ & 1,66 \\
\hline 15 & 8,61 & 3-phenyl-2-butenal & $\mathrm{C}_{10} \mathrm{H}_{10} \mathrm{O}$ & 1,7 \\
\hline 16 & 8,71 & $\begin{array}{l}\text { Oxalic acid, 2-isopropylphenyl } \\
\text { pentyl ester }\end{array}$ & $\mathrm{C}_{16} \mathrm{H}_{22} \mathrm{O}_{4}$ & 1,51 \\
\hline 17 & 8,93 & Benzenepropanenitrile & $\mathrm{C}_{9} \mathrm{H}_{9} \mathrm{~N}$ & 2,02 \\
\hline 18 & 9,25 & 1H-Indol-4-ol, 3-methyl- & $\mathrm{C}_{9} \mathrm{H}_{9} \mathrm{NO}$ & 1,4 \\
\hline 19 & 9,71 & Indole & $\mathrm{C}_{8} \mathrm{H}_{7} \mathrm{~N}$ & 3,08 \\
\hline 20 & 10,99 & 1H-Indole, 7-methyl- & $\mathrm{C}_{9} \mathrm{H}_{9} \mathrm{~N}$ & 2,27 \\
\hline 21 & 11,08 & $\begin{array}{l}\text { Benzeneacetic acid, 4-(1H-1,2,3,4- } \\
\text { tetrazol-1-yl)- }\end{array}$ & $\mathrm{C}_{9} \mathrm{H}_{8} \mathrm{~N}_{4} \mathrm{O}_{2}$ & 1,66 \\
\hline 22 & 11,21 & 3-Isobutyldihydropyrazin-2-one & $\mathrm{C}_{8} \mathrm{H}_{12} \mathrm{~N}_{2} \mathrm{O}$ & 1,8 \\
\hline 23 & 12,28 & 4-(4-Methylphenyl)pyridine & $\mathrm{C}_{12} \mathrm{H}_{11} \mathrm{~N}$ & 1,4 \\
\hline 24 & 12,32 & Pentadecane & $\mathrm{C}_{15} \mathrm{H}_{32}$ & 1,54 \\
\hline 25 & 14,66 & Heptadecane & $\mathrm{C}_{17} \mathrm{H}_{36}$ & 5,12 \\
\hline 26 & 16,24 & $\begin{array}{l}\text { 2-Pentadecanone, } 6,10,14- \\
\text { trimethyl- }\end{array}$ & $\mathrm{C}_{18} \mathrm{H}_{36} \mathrm{O}$ & 1,84 \\
\hline 27 & 16,81 & Hexadecanenitrile & $\mathrm{C}_{16} \mathrm{H}_{31} \mathrm{~N}$ & 3,63 \\
\hline 28 & 17,29 & $\begin{array}{c}\text { 5,10-Diethoxy-2,3,7,8-tetrahydro- } \\
\text { 1H,6H-dipyrrolo[1,2-a;1',2'- } \\
\text { d]pyrazine }\end{array}$ & $\mathrm{C}_{14} \mathrm{H}_{22} \mathrm{~N}_{2} \mathrm{O}_{2}$ & 2,9 \\
\hline 29 & 17,4 & n-Hexadecanoic acid & $\mathrm{C}_{16} \mathrm{H}_{32} \mathrm{O}_{2}$ & 10,96 \\
\hline 30 & 19,44 & Hexadecanamide & $\mathrm{C}_{16} \mathrm{H}_{33} \mathrm{NO}$ & 4,41 \\
\hline
\end{tabular}


Table 4:

\begin{tabular}{|c|c|c|}
\hline $\begin{array}{c}\text { Chemical shift } \\
(\mathrm{ppm})\end{array}$ & Type of protons & Area (\%) \\
\hline $0.5-1.5$ & $-\mathrm{CH}_{3},-\mathrm{CH}_{2}$ & 32.31 \\
\hline $1.5-3.0$ & $\mathrm{CH}_{3}-\mathrm{C}=\mathrm{O}, \mathrm{CH}_{3}-\mathrm{N}, \mathrm{Ar}-\mathrm{CH}_{3}, \mathrm{Ar}-\mathrm{CH}_{2}-$ & 29.61 \\
\hline $3.0-4.5$ & $\mathrm{CH}_{3}-\mathrm{C}=\mathrm{O},-\mathrm{CH}_{2} \mathrm{O}-,-\mathrm{CH}_{2}-\mathrm{N}-$ & 5.99 \\
\hline $4.5-6.0$ & $\mathrm{ArOCH}_{3}, \mathrm{HC}=\mathrm{C}-($ non-conjugated $)$ & 6.64 \\
\hline $6.0-9.5$ & $\mathrm{ArH},-\mathrm{CHO}$ & 25.45 \\
\hline
\end{tabular}



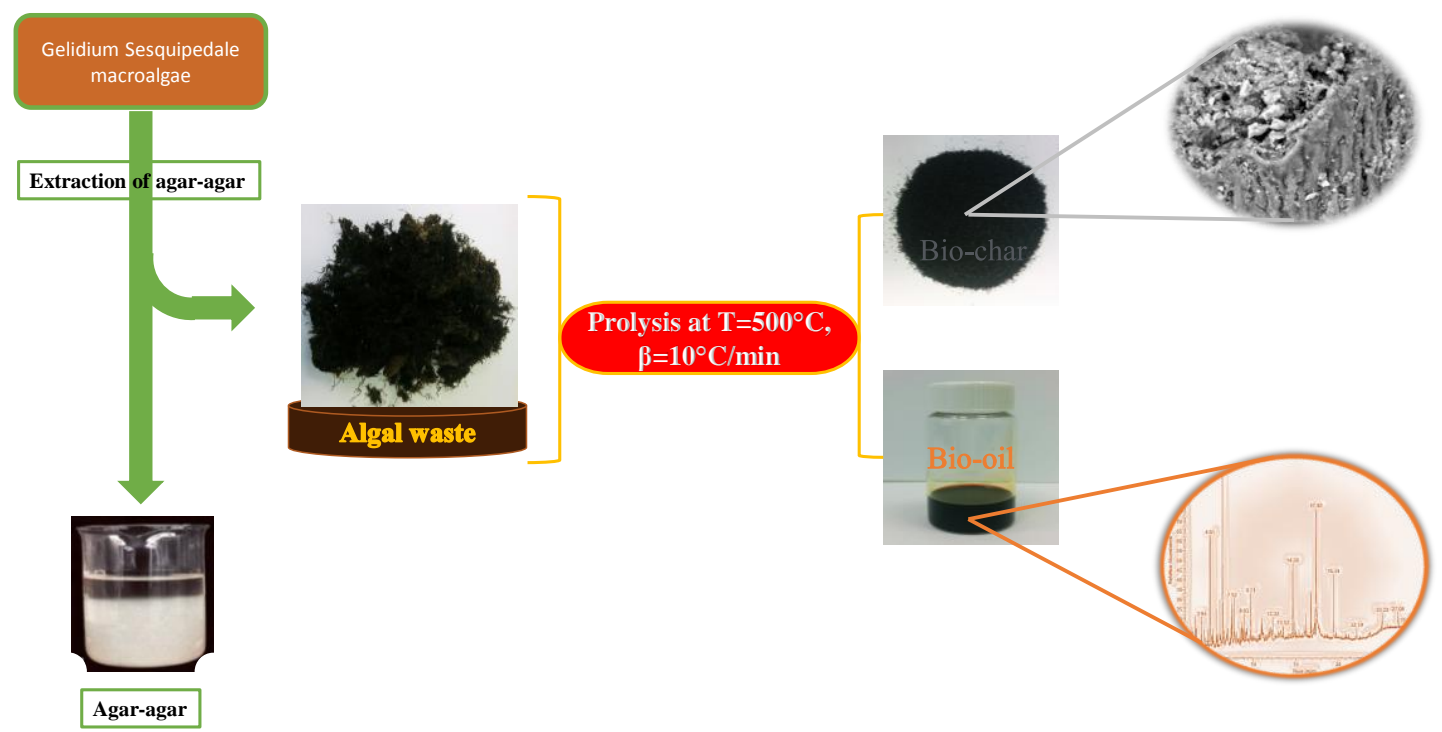
Waste algal was pyrolyzed to get value added materials: bio-oil and bio-char 